\title{
PERLINDUNGAN HUKUM BAGI ATLET SEPAKBOLA PROFESIONAL INDONESIA TERHADAP MANAJEMEN KLUB YANG MELAKUKAN WANPRESTASI
}

\author{
Syifa Usdurah \\ Magister Hukum \\ Fakultas Hukum Universitas Surabaya \\ syiffausd26@gmail.com
}

\begin{abstract}
Work agreemen between football clubs with a soccer player axisting in reality irregularities in the football world. Salary arrears problem is always the case and subject to clauses regarding whwther or not the soccer player of the Employment Act, to guaratee legal certainty for soccer players is less favorable for soccer players. Giving rise to disputes between the parties with football club soccerplayer who needs the remedies in accordance with applicable laws.
\end{abstract}

Keywords: Legal Protection, soccer player, club management, work agreement.

\begin{abstract}
Abstrak : Perjanjian kerja antara klub sepakbola dengan atlet sepakbola yang ada pada kenyataannya terjadi penyimpangan dalam dunia persepakbolaan. Masalah penunggakan gaji yang selalu terjadi dan klausul mengenai tunduk atau tidaknya atlet sepakbola terhadap Undang-Undang Ketenagakerjaan, hingga jaminan kepastian hukum bagi atlet sepakbola masih kurang menguntungkan bagi atlet sepakbola. Sehingga menimbulkan sengketa antara pihak klub sepakbola dengan atlet sepakbola yang membutuhkan upaya penyelesaian yang sesuai dengan undang-undang yang berlaku.
\end{abstract}

Kata Kunci: Perlindungan Hukum, Atlet Sepakbola, Manajemen Klub, Perjanjian kerja.

\section{PENDAHULUAN}

Sepakbola merupakan olahraga yang paling populer di dunia. Beberapa tahun belakangan ini sering terdengar kabar mengenai carut marutnya kondisi sepakbola negara ini. Salah satunya adalah kasus gaji atlet sepakbola professional di Indonesia yang tidak terbayarkan dan tertunggak. Mulai dari atlet lokal hingga atlet asing. Bahkan, beberapa di antaranya harus menghembuskan nafas terakhir di Indonesia karena sakit dan tidak mampu untuk berobat. Ada pula yang tidak bisa pulang ke negaranya karena tidak mempunyai ongkos bahkan ada atlet asing yang harus bekerja di warung yang pada akhirnya harus di deportasi ke negara asalnya. Di Indonesia sepakbola berada dibawah naungan Persatuan Sepakbola Seluruh Indonesia (selanjutnya disebut PSSI), sedangkan asosiasi tertinggi yang menaungi sepakbola dunia adalah Federation of International Football Association (selanjutya disebut FIFA).

Sengketa tersebut terus-menerus terjadi karena kurangnya perlindungan hukum terhadap atlet sepakbola professional di Indonesia dan pemahaman atlet sepakbola 
professional mengenai hak-haknya. Saat terjadi sengketa atlet sepakbola mengalami kebimbangan mengenai apa yang harus dilakukan, kemana harus mengadu dan siapa yang harus bertanggung jawab.

Sebagai contoh yang menarik untuk dibahas adalah perjanjian kerja/kontrak kerjanya atlet sepakbola profesional dengan pihak manajemen klub. Sebagaimana telah diatur bahwasanya atlet sepakbola profesional Indonesia harus membuat suatu perjanjian tercantum dalam pasal 57 ayat (8) dan (9) Peraturan Pemerintah Republik Indonesia Nomor 16 tahun 2007 Tentang Penyelenggraan Keolahragaan (selanjutnya disebut PP Penyelenggaraan Keolahragaan), dimana dalam pasal ini jelas menyebutkan bahwa atlet profesional harus membuat pejanjian berupa kontrak kerja yang berisi hak, dan kewajiban, dengan adanya kesepakatan dan pengaturan tentang upah,bonus, tunjangan, asuransi, masa berlaku, serta mekanisme penyelesaian perselisihan. Di dalam Burgelijk Wetboek (selanjutnya disebut BW) dan Undang-Undang Republik Indonesia Nomor 13 tahun 2003 (selanjutnya disebut UU Ketenagakerjaan) telah jelas mengatur mengenai perjanjian dan syarat sahnya suatu perjanjian.

Klausul perjanjian kerja/Kontrak kerja Atlet Sepakbola Indonesia dengan manajemen klub yang secara eksplisit mencantumkan bahwa, kontak atlet sepakbola bersifat khusus dan tidak tunduk pada UU Ketenagakerjaan. Hal ini yang membuat kebingungan atlet sepakbola semakin jelas. Permasalahan harus tunduk atau tidaknya suatu Perjanjian/Kontrak Kerja atlet sepakbola kepada UU Ketenagakerjaan menjadi problematika tersendiri. Pasalnya ada yang berpendapat bahwa UU Ketenagakerjaan tidak dapat berlaku untuk atlet sepakbola profesional, karena ada kekhususan dalam dunia olahraga, termasuk hukumnya dan hal ini dikenal sebagai Lex Sprotiva. Dimtiros Panagiotopoulos menyatakan bahwa ${ }^{1}$ :

"... Lex Sportiva is a legal order, which incorporates state-adopted law and the law adopted by the national and international bodies representing organized sport. These bodies operate to the standards of unions and in the context of the autonomy granted to such bodies and operate within states in a pyramid-like fashion and at international level in the form of a special relationship linking them to the relevant international sports federation. The law produced in this manner is thus a law which is, in essence, non-national law, which claims for itself direct and preferential application within sports legal orders and the par excellence law in sports life".

Ada juga yang menyebut Lex Sportiva sebagai global sport law. Ken Foster menjelaskan bahwa: ${ }^{2}$

"Global sports law, by contrast, may provisionally be defined as a transnational autonomous legal order created by the private global institutions that govern international sport". It is a sui generis set of principles created from transnational legal norms generated by the rules, and the interpretation thereof, of international sporting federations. This is a separate legal order that is globally autonomous. This implies

\footnotetext{
${ }^{1}$ Hinca Panjaitan, “Memperkenalkan Lex Sportiva di Indonesia Problema dan Tantangan Dunia Olabraga di Indonesia dan Keterkaitannya Aspek Hukan", http:/ / www.lexsportiva.co.id/?lang=\&page=content\&ids=6\&id=29 Di kunjungi pada 15 November 2016.
${ }^{2}$ Ken
Foster,
"Is There
Global

Sport

Law",

http://www2.warwick.ac.uk/fac/soc/law/elj/eslj/issues/volume2/number1/foster.pdf, h. 37 di kunjungi pada tanggal 15 November 2016
} 
that international sporting federations cannot be regulated by national courts or governments. They can only be self-regulated by their own internal institutions or by external institutions created or validated by them. Othervise they enjoy a diplomatic-type immunity from legal regulation".

Pernyataan kedua diatas dapat diartikan secara singkat bahwa, Lex Sportiva adalah peraturan yang di buat oleh Induk Organisasi Olahraga, semacam organisasi atau Statuta Organisasi olahraga, dimana setiap anggota organisasi tersebut harus tunduk terhadap organisasi atau statutanya.

Namun ada juga yang berpendapat bahwa UU Ketenagakerjaan berlaku untuk atlet sepakbola, sebab unsur-unsur telah terpenuhi. Pada pasal 1 angka 3 UU Ketenagakerjaan atlet sepakbola profesional telah memenuhi unsur sebagai pekerja/buruh dan unsur seperti adanya hubungan kerja, adanya pekerjaan, adanya upah, adanya perintah dan adanya unsur perjanjian kerja waktu tertentu. Tetapi ada kelemahan tersendiri jika atlet sepakbola tunduk pada UU Ketenagakerjaan seperti, hubungan hak dan kewajiban antara PSSI, hukum yang mengatur penyelesain sengketa, dan durasi jam kerja atlet sepakbola profesional. Sedangkan jika tidak tunduk sebagimana telah dinyatakan dalam klausul perjanjian/kontrak atlet berarti atlet sepakbola profesional berlaku hukum kontrak. Padahal kebijakan dasar dalam hukum ketenagakerjaan adalah untuk melindungi pihak yang lemah. Dalam hal ini pekerja/buruh dari kesewenang-wenangan majikan/pengusaha yang dapat timbul dalam hubungan kerja dengan tujuan memberikan perlindungan hukum dan mewujudkan keadilan sosial. ${ }^{3}$

Upaya penyelesaian sengketa hubungan kerja antara atlet sepakbola profesional dengan manajemen klub, jika merujuk pada Undang-Undang Republik Indonesia Nomor 2 tahun 2004 tentang Penyelesaian Perselisihan Hubungan Industrial (selanjutnya disebut UU Penyelesaian Perselisihan Hubungan Industrial) maka permasalahan penunggakan gaji akan diselesaikan di Pengadilan Hubungan Industrial. Namun hal ini bertentangan dengan Isi perjanjian kerja atlet sepakbola. Sedangkan dalam Pasal 88 Undang-Undang Nomor 3 tahun 2005 tentang Sistem Keolahragaan Nasional (selanjutnya disebut UU Sistem Keolahragaan Nasional) bahwa penyelesaian sengketa dengan cara mufakat dan jika belum terselesaikan dapat dilakukan melalui pengadilan yang sesuai dengan yuridiksinya.

Dalam pasal 68 statuta FIFA disebutkan bahwa,

"2. Recourse to ordinary courts of law is probibited unless specifically provided for in the FIFA regulations. Recourse to ordinary courts of law for all types of provisional measures is also probibited."

Dapat diartikan bahwa FIFA melarang penyelesaian dalam Pengadilan Negeri, kecuali telah diatur secara khusus oleh peraturan FIFA. Hal ini juga tercantum dalam Statuta PSSI pasal 70 ayat (1). Forum penyelesaian sengketa yang telah disediakan oleh FIFA antara lain, ${ }^{4}$ National Dispute Resulution Chamber(selanjutnya disebut NDRC), Dispute Resolution Chamber(selanjutnya disebut DRC), hingga yan paling tinggi Court of Arbitration for Sport(selanjutnya disebut CAS). National Dispute Resulution Chamber(NDRC) adalah yang paling murah biaya perkaranya namun belum juga terbentuk karena terdapat dualisme asosiasi

3 Agusmidah. 2011, Dilematika Hukum Ketenagakerjaan Tinjauan Politik. Hukum, Sofmedia, Jakarta, h.1

${ }^{4}$ Forum Penyelesaian Perselisihan dalam Kontrak Pesepakbola diIndonesia Masih Berbedabeda, http://www.appi-online.com/forum-penyelesaian-perselisihan-dalam-kontrak-pesepakbola-diindonesiamasih-berbeda-beda/ Dikunjungi pada 10 Oktober 2016 
atlet sepakbola profesional Indonesia yaitu Asosiasi Pesepakbola Profesional Indonesia( selanjutnya disebut APPI) yang diakuai oleh Fédération Internationale des Associations de Footballeurs Professionnels (selanjutnya disebut FIFpro) dan Asosiasi Atlet Sepakbola Nasional Indonesia(selanjutnya disebut APSNI) yang diakui oleh PSSI tapi tidak diakui oleh FIFpro. Sedangkan dalam tinggkat PSSI terdapat Arbitrase PSSI dan Komite Status Atlet.

Oleh karena itu mengingat begitu pentingnya perlindungan hukum terhadap atlet sepakbola seangat dibuthkan, maka penulis dapat merumuskan beberapa rumusan masalah sebagai berikut:

Pertama, Bagaimana bentuk perjanjian antara atlet sepakbola profesional Indonesia dengan pihak manajemen klub?

Kedua, Bagaimana upaya hukum bagi atlet sepakbola profesional terhadap pihak manajemen klub yang melakukan wanprestasi ?

Metode Penelitian yang penulis gunakan adalah menggunakan jenis penelitian yuridis normatif dan menggunakan pendekatan yang mengacu pada perundang-undangan atau juga disebut statute approach.

\section{PEMBAHASAN}

\section{Perjanjian Kerja Atlet Sepakbola Berdasarkan Burgelijk Wetboek}

Membahas masalah perjanjian atlet sepakbola, maka tidak bisa terlepas dari masalah Perikatan. Buku III Burgelijk Wetboek (selanjutnya disebut BW) tentang Perikatan (van Vebintensis) tidak memberikan definisi tentang apa yang dimaksud dengan Perikatan. Tetapi pada Pasal 1233 BW dinyatakan bahwa perikatan bisa lahir dari perjanjian ataupun dari undang-undang. Dengan demikian dapat disimpulkan bahwa suatu perjanjian adalah bersumber dari suatu perikatan.

\section{Bentuk Perjanjian}

Dalam BW tidak disebutkan secara sistematis tentang bentuk perjanjian. Namun pada dasarnya bentuk perjanjian tidak menjadi patokan untuk membuat suatu perjanjian. Hal ini disebabkan adanya penerepan asas kebebesasn berkontrak dalam suatu perjanjian. Ada beberapa bentuk perjanjian menurut bentuknya yang dapat dipilih oleh para pihak :

Pertama, Bentuk perjanjian tertulis adalah perjanjian yang dibuat oleh para pihak dalam bentuk tulisan. Perjanjian tertulis dapat dibagi menjadi tiga macam, yaitu: ${ }^{5}$

a) Perjanjian dibawah tangan ditandatangani oleh pibak yang bersangkutan saja. Dan perjanjian ini hanya mengikat para pibak dalam perjanjian tetapi tidak mempunya kekuatan mengikat pihak ketiga.

b) Perjanjian dengan saksi notaris untuk melegalisir tanda tangan para pibak yang bertujuan untuk. melegalisir kebenaran tanda tangan para pihak.

c) Perjanjian yang dibuat di hadapan dan oleh notaris dalam bentuk akta notareil. Bentuke perjanjian ini merupakan alat bukti yang sempurna dalam arti kata memiliki kekuatan bukum tetap. Tercantum dalam pasal $1682 \mathrm{BW}$. 
Kedua, Bentuk perjanjian lisan adalah perjanjian yang dibuat oleh para pihak cukup dengan lisan atau kesepakatan para pihak saja. Disamping itu pembagian bentuk perjanjian tersebut dikenal juga pembagian menurut bentuknya yang lain, yaitu perjanjian standar.

Perjanjian standar merupakan perjanjian yang telah dituangkan dalam bentuk formulir atau disebut juga perjanjian baku. Ciri-ciri perjanjian standar, yaitu:

a) Bentuk perjanjian standar tertulis.

b) Format perjanjian distandarisasi.

c) Syarat-syarat perjanjian (term) ditentukan oleh pengusaha.

d) Konsumen hanya memiliki pilihan untuk menerima atau menolak.

e) Penyelesaian sengketa melalui musyawarah atau badan peradilan.

f) Peranjian standar selalu menguntungkan perngusaha.

Adapun jenis-jenis perjanjian standar Menurut Mariam Darus Badrulzaman dapat dikelompokkan menjadi tiga jenis, yaitu : ${ }^{6}$

a. Perjanjian standar sepibak

b. Perjanjian standar yang ditetapkan pemerintah

c. Perjanjian standar yang ditentukan di lingkungan notaris

Dari penjabaran diatas jika dikaitkan dengan perjanjian kerja atlet sepakbola yang telah ada, bahwasanya perjanjian atlet sepakbola tersebut berbentuk tertulis dan merupakan perjanjian standar yang dimana telah memenuhi unsur sebagai perjanjian standar. Isi dalam perjanjian tersebut dibuat secara sepihak oleh pihak manajemen klub untuk seluruh atlet yang akan dikontrak atau akan bergabung dengan klub tersebut.

\section{Syarat Sahnya Perjanjian}

Menurut pasal 54 Undang-undang Ketenagakerjaan, Perjanjian kerja yang dibuat secara tertulis sekurang kurangnya harus memuat:

a) Nama, alamat perusabaan, dan jenis usaha

b) Nama, jenis kelamin, umur, dan alamat pekerjal pekerja

c) Jabatan atau jenis pekerjaan

d) Tempat pekerjaan

e) Besarnya upah dan cara pembayarannya

f) Syarat syarat kerja yang memuat hak dan kewajiban pengusaha dan pekerja atau pekerja

g) Mulai dan jangka waktu berlakunya perjanjian kerja

b) Tempat dan tanggal perjanjian kerja dibuat; dan ditanda tangani oleh para pihak dalam perjanjian kerja.

Apabila syarat pertama dan kedua tidak terpenuhi maka perjanjian itu dapat dibatalkan, artinya satu pihak tidak dapat mengajukan kepada pengadilan untuk membatalkan perjanjian yang disepakati. Akan tetapi, apabila para pihak tidak ada keberatan

\footnotetext{
${ }^{6}$ Mariam Darus Badrulzaman, 2005, “Aneka Hukum Bisnis”, Alumni, Bandung, h.47
} 
maka perjanjian tetap dianggap sah. Syarat ketiga dan keempat tidak terpenuhi, maka perjanjian batal demi hukum, artinya bahwa dari awal perjanjian itu dianggap tidak ada. ${ }^{7}$

Jadi, perjanjian atlet sepakbola yang ada tersebut sudah memenuhi syarat sahnya perjanjian dalam BW. Sebagaimana telah disebutkan diatas bahwa atlet sepakbola dan pihak manajemen klub telah sepakat untuk membuat suatu perjanjian kerja dan telah cakap. Dengan pekerjaan sebagai atlet sepakbola sebagai objek perjanjian, yang menimbulkan hak dan kewajiban pada masing-masing pihak. Dalam syarat keempat disebutkan suatu sebab yang halal atau suatu sebab yang diperbolehkan, yang dapat dikaitkan dengan perjanjian yang dibuat tidak bertentangan dengan undang-undang, ketertiban umum, dan kesusilaan.

\section{Asas-Asas Dalam Perjanjian}

Ada beberapa asas-asas hukum penting yang dikenal dalam BW adalah sebagai berikut :

Pertama, Asas Kebebasan Berkontrak, masalah yang berkaitan dengan perjanjian dalam BW diatur dalam buku III, yang menganut sistem terbuka dan asas kebebasan berkontrak atau freedom of contract yang maksudnya adalah BW memberikan kebebasan kepada para pihak yang mengadakan perjanjian dan menentukan isi perjanjian sepanjang tidak bertentangan dengan kesusilaan dan ketertiban umum. BW memberikan hak kepada para pihak untuk membuat dan melakukan kesepakatan, selama mereka memenuhi syarat-syarat sah perjanjian yang diatur dalam pasal $1320 \mathrm{BW}$. Asas ini dianalisis dari ketentuan pasal 1338 ayat (1) BW yang menyatakan semua perjanjian yang dibuat secara sah berlaku sebagai undang-undang bagi mereka yang membuatnya. Kebebasan ini adalah perwujudan dari keinginan untuk bebas membuat perjanjian dan merupakan pancaran dari hak asasi. ${ }^{8}$ Asas kebebasan berkontrak berhubungan dengan isi perjanjian, yaitu kebebasan menentukan tentang apa yang diperjanjikan, dengan siapa perjanjian itu dibuat, isi perjanjian, dan bentuk perjanjian.

Kedua. Asas Konsensualitas, asas ini merupakan penerapan dari sistem terbuka, dengan asas ini perjanjian yang dibuat memberikan kesempatan seluas-luasnya kepada para pihak untuk membuat suatu perjanjian yang akan mengikat mereka. Asas ini dapat disimpulkan dalam pasal 1320 angka 1 BW, dalam pasal tersebut ditentukan bahwa salah satu syarat sahny perjanjian yaitu adanya kesepakatan kedua belah pihak. Asas konsensualitas merupakan asas yang menyatakan bahwa perjanjian pada umunya tidak diadakan secara formal, atau dengan kata lain secara lisan.

Ketiga, Asas Personalitas, asas pernolitas ini dapat ditemui dalam rumusan pasal 1315 BW dan pasal 1340 BW. Dari kedua rumusan tersebut dapat disimpulkan bahwa pada dasarnya perjanjian hanya akan melahirkan hak-hak dan kewajiban daintara para pihak yang membuatnya. Ini berarti perjanjian yang dibuat oleh para pihak tersebut, demi hukum hanya akan mengikat para pihak yang membuatnya.

7 Salim H.S, 2003, op.cit, h. 25

8 Agus Yudha Hernoko, 2010, Hukum Perjanjian Asas Proporsionalitas dalam Kontrak Komersial, Kencana Prenada Media Group, Jakarta, h. 109 
Keempat, Asas Daya Mengikat ( Pacta Sunt Sevanda), didasarkan pada pendapat bahwa kekuatan mengikat kontrak karena adanya kesepakatan para pihak. Dalam perspektif BW daya mengikat dapat dicermati dalam rumusan pasal 1338 ayat (1) BW bahwa, "semua perjanjian yang dibuat secara sah berlaku sebagai undangundang bagi mereka yang membuatnnya". Pengertian berlaku secara sah sebagai undang-undang bagi mereka yang membuatnya menunjukkan bahwa undangundang sendiri mengakui dan menempatkan posisi para pihak dalam perjanjian sejajar dengan pembuat undang-undang.

Kelima, Asas Itikad Baik, asas ini tercantum dalam pasal 1338 ayat (3) BW yang menyatakan penegasan lebih lanjut sebagai pelaksanaan dari suatu perjanjian yang telah dibuat secara sah. Asas ini dibagi menjadi dua macam yaitu, itikad baik nisbi dan itikad mutlak. Pada itikad baik nisbi, orang memperhatikan sikap dan tingkah laku yang nyata dari subjek. Pada itikad baik mutlak, penilainnya terletak pada akal sehat dan keadilan, dibuat ukuran yang objektif untuk menilai keadaan menurut normanorma yang objektif. ${ }^{9}$

Telah jelas dalam BW telah diatur tentang asas-asas perjanjian, sebagaimana dikaitkan dengan perjanjian kerja atlet sepakbola, bahwa dengan adanya asas kebebasan berkontrak dan keterbukaan ini manajemen klub dapat membuat kesepkatan sesuai yang diinginkan dengan atlet sepakbola dengan klausul-klausul yang telah disepakati bersama.

\section{Perjanjian Kerja Atlet Sepakbola Berdasarkkan Undang-Undang Nomor 13 tahun 2003 Tentang Ketenagakerjaan}

Pengertian pekerja/buruh berdasarkan pasal 1 angka 3 UU Ketenagakerjaan adalah setiap orang yang bekerja dengan menerima upah atau imbalan dalam bentuk lain. Pekerja/buruh merupakan bagian dari tenaga kerja yaitu tenaga kerja yang bekerja di dalam hubungan kerja, di bawah perintah pemberi kerja (bisa perseorangan, pengusaha, badan hukum, atau badan lainnya) dan atas jasanya dalam bekerja yang bersangkutan menerima upah atau imbalan dalam bentuk lain. ${ }^{10}$ Atlet sepakbola dapat dikatakan sebagai pekerja/buruh sebab disini atlet menyumbangkan tenaganya dalam sebuah team yang dinaungi sebuah klub untuk mendapatkan keuntungan.

Unsur-unsur hubungan kerja berdasarkan Pasal 1 angka 15 UU ketenagakerjaan disebutkan bahwa hubungan kerja adalah hubungan anatara pengusaha dengan pekerja/buruh berdasarkan perjanjian kerja, yang mempunyai unsur pekerjaan,upah dan perintah. Berdasarkan pengertian hubungan kerja tersebut dapat ditarik beberapa unsur yakni: ${ }^{11}$

Pertama, Adanya unsur pekerjaan. Pekerjaan disini berarti segala perbuatan yang harus di lakukan oleh pekeja/buruh untuk kepentingan pengusaha sesuai isi perjanjian

${ }^{9}$ Ibid. h.11

${ }^{10}$ Devi Rahayu, 2011, “Hukum Ketenagakerjaan Teori dan Studi Kasus”, Elmatera,Yogyakarta, h. 35

${ }^{11}$ Lalu Husni, Op.cit, h.65-66 
kerja. ${ }^{12}$ Selain itu dalam suatu perjanjian kerja itu haruslah ada pekerjaan yang dipejanjikan (objek perjanjian) dan pekerjaan itu haruslah dilakukan sendiri oleh pekerja/buruh.

Kedua, Adanya upah, upah di sini berarti merupakan imbalan prestasi yang dibayarkan oleh pengusaha kepada pekerja/buruh atas pekerjaan yang telah dilakukan oleh pekerja atau buruh. Upah diterima dan dinyatakan dalam bentuk uang atau bentuk lain sebagai imbalan dari pengusaha atau pemberi kerja kepada pekerja/buruh yang ditetapkan dan dibayarkan menurut suatu perjanjian, kesepakatan, atau perundang-undangan, termasuk tunjangan bagi pekerja/buruh dan keluarganya atas suatu pekerjaan dan/atau jasa yang telah dilakukan. ${ }^{13}$

Ketiga, Adanya perintah, perintah merupakan unsur yang ketiga. Perintah merupakan unsur yang paling khas dalam hubungan kerja, maksudnya pekerjaan yang dilakukan oleh pekerja/buruh berada di bawah perintah pengusaha. ${ }^{14}$

Dari uraian di atas kontrak atlet sepak bola dengan manajemen klub sepakbola merupakan hubungan kerja, dimana memenuhi unsur seperti adanya pekerjaan, adanya upah dan adanya perintah. Atlet sepak bola mempunyai pekerjaan yaitu, memberikan jasanya dengan kemampuan bermain sepak bola dan bermain dengan baik guna menaikan prestasi klub kemudian mendapatkan upah dan juga atlet sepak bola dalam bekerja juga karena adanya perintah dari manajemen klub.

\section{Bentuk Perjanjian}

Dalam pasal 51 UU Ketenegakerjaan telah diatur :

1) perjanjian kerja dibuat secara tertulis atau lisan

2) perjanjian kerja yang dipersyaratkan secara tertulis dilaksanakan sesuai dengan peraturan perundang-undangan yang berlaku.

Jika perjanjian kerja dibuat secara tertulis, maka didalam perjanjian harus memuat sebagaimana yang tercantum dalam pasal 54 UU Ketenagakerjaan, Perjanjian kerja yang dibuat secara tertulis sekurang kurangnya harus memuat:

a. Nama, alamat perusabaan, dan jenis usaha

b. Nama, jenis kelamin, umur, dan alamat pekerja/ burub

c. Jabatan atau jenis pekerjaan

d. Tempatpekerjaan

e. Besarmya upah dan cara pembayarannya

f. Syarat syarat kerja yang memuat hak dan kewajiban pengusaha dan pekerja atau burub

g. Mulai dan jangka waktu berlakunya perjanjian kerja

b. Tempat dan tanggal perjanjian kerja dibuat; dani. tanda tangan para pibak dalam perjanjian kerja.

12 Adrian Sutedi, 2009, “Hukum Perburuban”, Sinar Grafika, Jakarta, h. 47

13 Ibid

14 Ibid, h. 48 
Dari urain diatas bahwa dalam perjanjian kerja/kontrak atlet sepakbola ada yang tidak klop dengan isi pasal 54 huruf e UU Ketenagakerjaan, pasalnya di dalam perjanjian kerja atlet sepakbola tersebut tidak disebutkan nominal dan cara pembayaran gaji atlet sepakbola yang bersangkutan.

\section{Syarat Sahnya Perjanjian Kerja}

Berdasarkan pasal 1 angka 14 UU Ketenagakerjaan, perjanjian kerja adalah perjanjian antara pekerja/buruh dan pengusaha atau pemberi kerja yang memuat syaratsyarat kerja, hak dan kewajiban kedua belah pihak. Menurut Iman Soepomo bahwa perjanjian kerja adalah suatu perjanjian dimana pihak kesatu (buruh), mengikatkan diri untuk bekerja dengan menerima upah dari pihak kedua yakni majikan dan majikan mengikatkan diri untuk memperkerjakan buruh dengan membayar upah. ${ }^{15}$

Berdasarkan pasal 52 UU Ketenagakerjaan disebutkan bahwa perjaanjian kerja dibuat atas dasar :

1. Kesepakatan kedua belah pibak

2. Kemampuan atau kecakapan melakukan perbuatan bukum

3. Adanya pekerjaan yang diperjanjikan; dan

4. Pekerjaan yang diperjanjikan tidak bertentangan dengan ketertiban umum, kesusilaan, dan peraturan perundang-undangan yang berlaku.

ketentuan mengenai pasal 52 UU Ketenagakerjaan ini sebenarnya sama dengan syarat sahya perjanjian pada pasal 1320 BW. Kesepakatan kedua belah pihak yang lazim disebut kesepakatan bagi yang mengikatkan dirinya maksudnya bahwa pihak-pihak yang mengadakan perjanjian kerja harus setuju/sepakat, seia-sekata mengenai hal-hal yang diperjanjikan. Apa yang dikehendaki pihak yang satu dikehendaki pihak yang lain. Pihak pekerja menerima pekerjaan yang ditawarkan, dan pihak pengusaha menerima pekerjaan tersebut untuk dipekerjakan. ${ }^{16}$

Kemampuan atau kecakapan kedua belah pihak yang membuat perjanjian maksudnya pihak pekerja maupun pengusaha cakap membuat perjanjian. Seseorang dipandang cakap membuat perjanjian jika yang bersangkutan telah cukup umur. Ketentuan hukum ketenagakerjaan memberikan batasan umur minimal 18 tahun pasal 1 angka 26 UU Ketenagakerjaan dikatakan cakap membuat perjanjian jika seseorang tersebut tidak terganggu jiwanya/waras. ${ }^{17}$

Telah jelas bahwa kontrak atlet sepak bola professional dengan manajemen klub adalah sah sebagai perjanjian kerja, karena semua syarat sah-nya perjanjian kerja tersebut terpenuhi seperti, adanya kesepakatan antara atlet sepak bola dengan klub, kemampuan atau kecakapan melakukan perbuatan hukum, adanya pekerjaan yang diperjanjikan dan pekerjaan tersebut tidak bertentangan dengan ketertiban umum, kesusilaan, dan peraturan perundang-undangan yang berlaku.

15 Lalu Husni, 2006, Pengantar hukum Ketenagakerjaan Indonesia, Grafindo, Jakarta, h.54

16 Ibid

${ }^{17}$ Ibid, h. 57-58 


\section{Jenis Perjanjian Kerja}

Jenis-jenis perjanjian kerja berdasarkan pasal 56 ayat 1 UU Ketenagakerjaan terdiri atas Perjanjian Kerja Waktu Tertentu (selanjutnya disebut PKW'T) dan Perjanjian Kerja Waktu Tidak Tertentu (selanjutnya disebut PKWTT). ${ }^{18}$ Berdasarkan Pasal 1 angka 1 Keputusan Menteri Tenaga Kerja dan Transmigrasi Republik Indonesia Nomor KEP.100/MEN/VI/2004 Tentang Pelaksanaan Perjanjian Kerja Waktu Tertentu disebutkan bahwa, Perjanjian kerja waktu tertentu adalah perjanjian kerja antara pekerja/buruh dengan pengusaha untuk mengadakan hubungan kerja dalam waktu tertentu atau untuk pekerja tertentu. Jadi, perjanjian kerja waktu tertentu maksudnya dalam perjanjian telah ditetapkan suatu jangka waktu yang dikaitkan dengan lamanya hubungan kerja antara pekerja/buruh dengan pengusaha. ${ }^{19}$ Sedangkan dalam pasal 59 UU Ketenagakerjaan di sebutkan mengenai syarat-syarat PKW'T atau pekerjaan yang termasuk dalam PKW'T sebagai berikut;

\section{a. Pekerjaan yang sekali selesai atau yang sementara sifatnya \\ b. Pekerjaan yang diperkirakan penyelesaiannya dalam waktu tidak terlalu lama dan paling lama 3 (tiga) tabun; \\ c. Pekerjaan yang bersifat musiman; atau \\ d. Perkerjaan yang berbubungan dengan produk baru, kegiatan baru, atau produk tambahan yang masib dalam percobaan atau penajajakan.}

PKWT tidak dapat diadakan untuk pekerjaan yang bersifat tetap. PKWT dapat diperpanjang atau diperbaruhi. Dari uraian mengenai PKWT tersebut dapat dilihat bahwa atlet sepak bola dibatasi oleh waktu tertentu karena atlet sepak bola bekerja jika ada suatu keadaan tertentu yaitu adanya musim kompetisi sepak bola yang diputar yang jangka waktunya sekitar 10 bulan dalam setahun dan perjanjian kerja/ kontrak kerja atlet sepakbola bisa diperbaruhi sesuai dengan kesepakatan kedua belah pihak. Sehingga, atlet sepakbola statusnya merupakan PKWT.

\section{Hubungan Hukum Antara Atlet Sepakbola dengan Pihak Manajemen}

Dari uraian tersebut di atas dapat dilihat bahwa atlet sepakbola merupakan pekerja/buruh. Memenuhi unsur-unsur dalam hubungan kerja dan memenuhi syarat sah dalam perjanjian menurut BW maupun UU Ketenagakerjaan. Kemudian kembali kepada rumusan masalah awal, tunduk atau tidaknya atlet sepakbola kepada UU Ketenagakerjaan. Jika melihat kesimpulan di atas dan juga atlet sepakbola memenuhi segala unsur-unsur dalam ketenagakerjaan seperti unsur pekerja/buruh, unsur hubungan kerja dan syarat perjanjian kerja. Maka sudah seharusnya atlet sepakbola tunduk pada UU Ketenagakerjaan.

Di Indonesia terdapat UU Sistem Keolahragaan Nasional Pasal 1 angka 1 UU Sistem Keolahragaan Nasional menjelaskan bahwa yang dimaksud dengan keolahragaan adalah "segala aspek yang berkaitan dengan olahraga yang memerlukan pengaturan, pendidikan, pelatihan, pembinaan, pengembangan, dan pengawasan". Dari pengertian

\footnotetext{
${ }^{18}$ F.X. Djumiadji, 2010, Perjanjian Kerja, Edisi Revisi, Sinar Grafika, Jakarta, h.11-12

19 Adrian Sutedi, Loc.Cit.
} 
tersebut di atas dapat ditafsirkan bahwa dalam kegiatan olahraga memerlukan pengaturan, pendidikan, pelatihan, pembinaan, pengembangan dan pengawasan. Salah satunya adalah pengaturan mengenai hubungan kerja antara klub sepakbola dengan atlet sepakbola professional yang timbul dari adanya kompetisi atau kejuaraan dibidang olahraga dan merupakan salah satu bentuk kegiatan olahraga.

Berdasarkan asas prefrensi, khusus untuk kegiatan olahraga, hubungan hukum antara atlet sepakbola dan klub sepakbola berlaku ketentuan dalam UU Sistem Keolahragaan Nasional. Namun, dalam pasal 55 ayat 2 UU Sistem Keolahragaan Nasional disebutkan bahwa,

"Setiap orang dapat menjadi olahragawan profesional setelah memenuhi persyaratan:

a. pernah menjadi olahragawan amatir yang mengikuti kompetisi secara periodik;

b. memenubi ketentuan ketenagakerjaan yang dipersyaratkean;

c. memenubi ketentuan medis yang dipersyaratkan; dan

d. memperoleh pernyataan tertulis tentang pelepasan status dari olabragawan amatir menjadi olahragawan profesional yang diketahui oleh induk organisasi cabang olahraga yang bersangkutan."

dari ketentuan pasal 55 ayat 2 huruf b tersebut dapat kita lihat bahwasannya UU Sistem keolahragaan Nasional mengambalikan pengaturan kepada UU Ketenagakerjaan. Jika terjadi sengketa antara UU Ketenagakerjaan dengan UU Sistem Keolahragaan. Karena UU Sistem Keolahragaan Nasional merupakan lex specialis dari UU Ketenagakerjaan, maka saat terjadi sengketa antara kedua UU tersebut yang berlaku adalah norma pada UU Sistem Keolahragaan Nasional. Sehingga, pengaturan mengenai hubungan kerja atlet sepakbola dan manajemen klub sepakbola berlaku ketentuan dalam UU Ketenagakerjaan kecuali apa yang diatur khusus dalam UU Sistem Keolahragaan Nasional.

Tetapi, menurut penulis ada kelemahan pada UU Sistem Keolahragaan Nasional dan UU Ketenagakerjaan, jika diterapkan secara mutlak tanpa memperhatikan peraturanperaturan FIFA dan PSSI terhadap atlet sepak bola dan klub sepak bola di Indonesia. Hal tersebut karena dalam UU Ketenagakerjaan masih belum ada ketentuan yang mengakomodir kepentingan atlet sepak bola professional. Karena adanya pengaturan khusus di dunia olahraga, termasuk di bidang hukum, atau dikenal sebagai Lex Sportiva. Sehingga terdapat kekosongan hukum, ketidakcocokan dan disharmonisasi antara sistem hukum nasional dengan hukum olahraga(Peraturan FIFA).

Adapun beberapa hal yang menjadi kritik penulis terhadap UU ketenagakerjaan jika diterapkan pada atlet sepakbola professional dan klub sepakbola sebagai berikut:

Pertama, Waktu Kerja Atlet Sepak bola Professional. Mengenai waktu kerja, atlet sepak bola tidak mungkin bekerja menurut jam kerja seperti yang diatur dalam UU Ketenagakerjaan karena atlet tidak mungkin bertanding atau berlatih secara rutin selama 7 jam atau 8 jam setiap hari. Selain itu juga dalam pasal 3 Keputusan Menteri Tenaga Kerja dan Transmigrasi Republik Indonesia Nomor KEP.233/MEN/2003 Tentang Jenis dan Sifat Pekerjaan yang Dilakukan Secara 
Terus Menerus yang merupakan ketentuan penyimpangan terhadap pasal 77 UU Ketenagakerjaan, Atlet (atlet sepakbola) tidak disebutkan di dalamnya.

Kedua, Hukum yang Dipakai jika Menyelesaikan Sengketa Atlet Sepak Bola dengan Klub melalui Pengadilan Hubungan Industrial. Sengketa hubungan kerja antara klub dan atlet sepakbola tidak hanya sebatas pada perselisihan mengenai upah. banyak perselisihan yang bisa saja terjadi, seperti sengketa mengenai ITC (International Transfer Certificate), sengketa mengenai perselisihan solidarity mechanism, training compensation, sengketa pemilikan atlet, sengketa sah atau tidaknya atlet, sengketa mengenai penggunaan atlet untuk Tim Nasional, sengketa tentang transfer dan peminjaman atlet, sengketa antara klub, pelatih. agen dan atlet. Jika menyelesaiakan melalui Pengadilan hubungan Industrial, karena hal tersebut tidak diatur dalam Peraturan perundang-undangan maupun UU Ketenagakerjaan.

\section{Sikap FIFA Sebagai Federasi Tertinggi Terhadap UU Ketenagakerjaan Suatu Negara}

FIFA tidak menolak adanya UU Ketenegakerjaan di suatu Negara, hal ini dapat dilihat dalam Regulation on the Status and Transfer of Player (selanjutnya disebut RSTP) sendiri pada article 1 paragraph 3 point b di sebutkan bahwa,

"Each association shall include in its regulations appropriate means to protect contractual stability, paying due respect to mandatory national law and collective bargaining agreements."

Dapat diterjemahkan secara singkat bahwa setiap asosiasi harus mencakup peraturan cara yang tepat untuk melindungi stabilatas kontrak, tunduk kepada hukum nasional dan perjanjian kerja bersama. Namun yang sangat ditakutkan adalah jika hukum disuatu negara bertentangan dengan statuta FIFA dan Peraturan-Peraturan yang dibuat oleh FIFA. Pasalnya kekuatan hukum yang dibuat oleh FIFA bisa lebih kuat dari hukum nasional. Menurut penulis, UU ketenagakerjaan sebagai Hukum Nasional harus tetap mempertimbangkan prinsip-prinsip khusus dalam kontrak atlet sepak bola yang disebutkan di dalam RSTP tersebut dan peraturan yang lain.

\section{Upaya Penyelesaian Sengeketa Antara Atlet Sepakbola dan Pihak Manajemen Klub Berdasarkan Perjanjian Kerja/Kontrak Kerja Atlet}

Suatu hubungan kerja di dalam dunia sepakbola dapat berlangsung secara terusmenerus, jika hubungan antara pihak atlet sepakbola dan manajemen klub terdapat sengketa di kemudian hari, maka salah satu cara penyelesaiannya dengan litigasi dan nonlitigasi. Litigasi adalah penyelesaian sengketa melalui pengadilan, sedangkan non-litigasi adalah penyelesaian sengketa di luar pengadilan.

Penyelesaian sengketa sepakbola menggunakan cara non-litigasi sebagaimana telah disebutkan pada pasal 21 perjanjian kerja/kontrak kerja bahwa:

"Dalam hal terjadinya sengketa, perselisihan dan konflik diantara para pihak sehubugan dengan perjanjian ini, maka sengketa, perselisihan atau konflik tersebut akan 
diselesaikan secara musyawarah untuk mencapai mufakat dalam jangka waktu 30 (tiga puluh) hari.“

"Apabila dalam jangka waktu 30 (tiga puluh) hari perjanjian ini perselisihan tersebut tidak dapat di selesaikan secara musyawarah mufakat, maka para pihak sepakat menyelesaikan perselisihan tersebut melalui BAKI yang keputusannya bersifat final." Dari perjanjian kerja/kontrak kerja atlet pasal 21 dapat dijelaskan, jika terjadinya sengketa antara pihak atlet sepakbola dengan manajemen klub menggunakan cara sesuai dengan pasal 21 ayat (1) yaitu melalui musyawarah unuk mencapai mufakat antara kedua belah pihak.

Penyelesaian sengketa antara atlet sepakbola dengan pihak manajemen klub melalui musyawarah adalah hanya melibatkan kedua belah pihak saja, tanpa campur tangan pihak ketiga. Hal ini dlakukan agar sengketa antara kedua belah pihak cepat selesai. Pada dasarnya musyawarah dilakukan dengan cara kekeluargaan. Hal ini dapat dikatakan agar tidak merusak hubungan baik antara atlet sepakbola dengan pihak manajemen klub. Apabila penyelesaian sengketa dengan cara musyawarah tidak menemui jalan keluar atau solusinya, maka sengketa akan diselesaikan dengan cara sesuai dengan pasal 21 angka 21.2 yaitu Badan Arbitrase Keolahragaan Indonesia (selanjutnya disebut BAKI). Menurut pasal 1 angka 1 Undang-Undang Nomor 30 tahun 1999 tentang Arbitrase dan Alternatif Penyelesaian Sengketa( selanjutnya disebut UU Arbitrase dan Alternatif Penyelesaian Sengketa) yang di maksud dengan arbitrase adalah cara penyelesaian sesuatu sengketa perdata diluar peradilan umum yang didasarkan pada perjanjian yang dibuat secara tertulis oleh para pihak yang bersengketa.

Dalam penyelesaian sengketa BAKI bertindak sebagai lembaga Arbitrase, sebagaimana telah disebutkan dalam pasal 1 angka 8 UU Arbitrase dan Alternatif Penyelesaian Sengketa tentang lembaga arbitrase adalah badan yang dipilih oleh para pihak yang bersengketa untuk memberikan putusan mengenai sengketa tertentu, lembaga tersebut juga dapat memberikan pendapat yang mengikat mengenai suatu hubungan hukum tertentu dalam hal belum timbul sengketa.

Pada umumnya lembaga arbitrase mempunyai kelebihan dibandingkan dengan lembaga peradilan, kelebihan tersebut antara lain: ${ }^{20}$

a. Dijamin kerahasiaan sengketa para pibak

b. Dapat dihindari kelambatan yang diakibatkan karena hal prosedural dan administartif.

c. Para pibak dapat memilih arbiter yang menurut keyakinannya mempunyai pengetabuan, pengalaman, serta latar belakang yang cukup mengenai masalah yang disengketakan, jujur dan adil.

d. Para pibak dapat menentukan piliban bukum untuk penyelesaian masalah serta proses dan teat penyelenggaraan arbitrase.

e. Putusan arbitrase merupakan putusan yang mengikat para pibak dengan melalui tatacara (prosedur) sederbana saja ataupun langsung dapat dilaksanakan.

${ }^{20}$ Munir Fuady, 2000, “Arbitrase Nasional”, cetakan I, Citra Adity Bakti, Bandung, h.13 
Namun pada kenyataannya tidak semua benar, satu-satunya kelebihan arbitrase terhadap pengadilan adalah sifat kerahasiannya. Karena keputusannya tidak dipublikasikan atau tidak diberikan kepada masyarakat luas.

Aribitrase yang diatur dalam UU Arbitrase dan Alternatif Penyelesaian Sengketa merupakan cara penyelesaian suatu sengketa yang dibuat berdasarkan atas perjanjian tertulis dari para pihak. Penyelesaian sengketa mengguna arbitrase memiliki ciri tersendiri. Hal ini di ungkupkan oleh Munir Fuady, karateristik yuridis arbitrase: ${ }^{21}$

a. Adanya kontroversi diantara para pihak.

b. Kontroversi tersebut diajukan kepada arbitrase.

c. Arbiter diajukan oleh para pibak atau ditunjuk oleb badan tertentu.

d. Arbiter adalah pibak diluar badan peradilan umum.

e. Dasar pengajuan sengketa ke arbitrase adalah perjanjian.

f. Arbiter melakukan pemeriksaan sengketa.

g. Setelah memeriksa sengketa, arbiter akan melakukan dan memberikan putusan arbitrase tersebut dan mengikat para pihak.

Pada dasarnya para pihak yang bersengketa (pihak manajemen klub dan atlet sepakbola) dapat menyatakan perjanjian untuk menentukan bahwa arbiter dalam memutus perkara wajib berdasarkan ketentuan hukm atau sesuai dengan rasa keadilan. Dalam hal ini arbiter diberi kebebasan untuk memberikan putusan berdasarkan keadilan dan kepatutan, maka peraturan perundang-undangan dapat dikesampingkan. Akan tetapi dalam hal tertentu, hukum bersifat memaksa yang harus diterapkan dan tidak dapat dikesampingkan atau diabaikan oleh arbiter.

Semua penyelesaian sengketa yang diserahkan kepada BAKI merupakan langkah terakhir yang keputusannya bersifat final dan mengikat. Pihak yang bersengketa yaitu atlet sepakbola dengan pihak manajemen klub harus menjalankan atau memenuhi keputusan BAKI dengan penuh rasa tanggungjawab. Hal ini dimaksudkan untuk menjaga jangan sampai penyelesaian sengketa melalui cara arbitrase yang ditempuh BAKI menjadi berlarutlarut arau tidak terselesaikan.

Tetapi dalam prakteknya, penyelesaian sengketa yang dilakukan oleh pihak manajemen klub tidak menggunakan cara yang sesuai dengan kontrak kerja yang telah disepakati. Manajemen klub menggunakan cara opsi (pilihan) yang tidakdicantumkan dalam kontrak keja atlet sepakbola.

Pihak manajemen klub memeberikan dua pilihan kepada para atlet menyangkut remunerasi (penggajian), yang pertama pihak manajmen klub memberikan remunerasi (penggajian) yang terhutang atau belum terselesaikan secara penuh, tetapi belum ada kepastian kapan akan diberikan. Kedua pihak manajemen klub memberikan remunerasi (penggajian 20\% dua bulan gaji dalam waktu satu bulan.

\section{Penyelesaian Sengketa berdasarkan Undang-Undang Nomor 3 Tahun 2005 tentang Sistem Keolahragaan Nasional}


Jika kita lihat dalam UU No 3 Tahun 2005 Tentang Sistem Keolahragaan Nasional pasal 88 juga diatur mengenai tata cara penyelesaian sengketa keolahragaan.

\section{Pasal 88}

1) Penyelesaian sengketa keolahragaan diupayakan melalui musyawarah dan mufakat yang dilakukan oleh induk organisasi cabang olahraga.

2) Dalam hal musyawarah dan mufakat sebagaimana dimaksud pada ayat (1) tidak tercapai, penyelesaian sengketa dapat ditempub melalui arbitrase atau alternatif penyelesaian sengketa sesuai dengan peraturan perundang-undangan.

3) Apabila penyelesaian sengketa sebagaimana dimaksud pada ayat (2) tidak tercapai,penyelesaian sengketa dapat dilakukan melalui pengadilan yang sesuai dengan yurisdiksinya.

kemudian yang dimaksud dengan sengketa keolahragaan dalam pasal 88 UU Sistem Keolahragaan Nasional. Dalam UU Sistem Keolahragaan Nasional tidak dijelaskan secara eksplisit mengenai apa yang dimaksud tentang sengketa keolahragaan. Tetapi, jika kita menarik dari pasal 1 angka 1 UU Sistem Keolahragaan Nasional yang dimaksud dengan keolahragaan adalah "segala aspek yang berkaitan dengan olahraga yang memerlukan pengaturan, pendidikan, pelatihan, pembinaan, pengembangan, dan pengawasan". Maka, dapat disimpulkan bahwa sengketa keolahragaan yang dimaksudkan adalah sengketa yang dapat saja muncul dari segala aspek yang berkaitan dengan olahraga (sepakbola) baik dari sejak pengaturan, pendidikan, pelatihan, pembinaan, pengembangan maupun pengawasan yang berkenaan dengan olahraga (sepakbola) sebagai suatu kegiatan yang sistematis untuk mendorong, membina serta mengembangkan potensi jasmani, rohani dan sosial. ${ }^{22}$

Jika dirumuskan lebih lengkap, maka rumusan definisi sengketa sepakbola professional dalam pasal 88 ayat 1 UU Sistem Keolahragaan Nasional dapat dijelaskan bahwa kegiatan pengaturan, penyelenggaraan dan pengelolaan kompetisi sepakbola professional dapat menimbulkan sengketa dan karenanya menjadi objek yang dimaksudkan dalam rumusan sengketa sepakbola professional. Sengketa sesama pengurus sepakbola atau sengketa antara atlet dan klub, atau sengketa antara klub dan liga sebagai pengelola kompetisi, serta sengketa dengan pihak ketiga di luar stakeholder sepakbola dapat saja terjadi dan masuk ke dalam kategori sengketa sepak bola professional. ${ }^{23}$

Dalam Pasal 88 mengamanatkan bahwa penyelesaian sengketa keolahragaan terlebih dahulu diselesaikan melalui musyawarah dan mufakat, kemudian jika tidak tercapai kesepakatan maka diselesaikan melalui arbitrase atau alternatif penyelesaian sengketa sesuai dengan peraturan perundang-undangan kemudian jika penyelesaian sengketa melalui jalur arbitrase tidak tercapai maka dapat berlanjut melalui pengadilan sesuai dengan yurisdiksinya.

Hal ini berbeda dengan apa yang diatur pada UU Penyelesaian Perselisihan Hubungan Industrial, dimana tidak semua sengketa dapat diselesaikan melalui arbitrase. Dalam UU Sistem Keolahragaan Nasional terdapat tahapan untuk menyelesaikan sengketa,

\footnotetext{
${ }^{22}$ Hinca Panjaitan, 2011 , “Kedaulatan Negara Vs Kedaulatan FIFA”,Kompas Gramedia ,Jakarta, h. 135

23 Ibid, h. 295
} 
mulai dari musyawarah dan mufakat kemudian arbitrase dan pengadilan sebagai pilihan terakhir.

Sehingga berdasarkan pasal 88 UU Sistem Keolahragaan Nasional ini, Arbitrase tidak lagi menjadi lembaga alternatif penyelesaian sengketa tapi menjadi salah satu lembaga penyelesaian sengketa karena kedudukan arbitrase tidak sejajar dengan pengadilan tetapi ada hierarki yang mana arbitrase didahulukan ketimbang pengadilan. Yang menarik dalam pasal 88 ayat 3 UU Sistem Keolahragaan Nasional adalah pemilihan pengadilan sebagai lembaga penyelesaian sengketa yang bersifat optimal karena terdapat kata „dapat". Sehingga jika atlet sepakbola professional dan klub dalam kontrak kerja sepakat untuk tidak memilih pengadilan sebagai lembaga penyelesaian sengketa namun memilih forum penyelesaian seperti apa yang diatur dalam peraturan FIFA dan PSSI adalah sah dan tidak menyalahi ketentuan dalam peraturan perundang-undangan.

Hal tersebut lumrah terjadi pada kontrak atlet sepakola professional di Indonesia yang tidak memilih Pengadilan Hubungan Industrial sebagai forum penyelesaian sengketa sebagaimana diamanatkan dalam UU Ketenagakerjaan jo UU Penyelesaian Perselisihan Hubungan Industrial jika terjadi perselisihan hubungan industrial, tetapi mengikuti tatacara penyelesaian sengketa yang sesuai dengan Statuta FIFA dan Statuta PSSI. Hal tersebut untuk menghormati apa yang ada dalam Statuta FIFA dan Statuta PSSI untuk menghindari penyelesaian melalui pengadilan dan menyelesaikan melalui lembaga arbitrase yang disediakan dalam statuta.

\section{Penyelesaian Sengketa yang disediakan Berdasarkan Statuta PSSI}

Ada beberapa forum yang ditunjuk oleh PSSI untuk penyelesaian suatu sengketa yang terjadi dalam ruang lingkup sepak bola Indonesia yaitu :

Pertama, Badan Arbitrase PSSI merupakan badan arbitrase yang dibentuk sendiri oleh PSSI berdasarkan Surat Keputusan Nomor: SKEP/87/JAH/XI/2013 tentang Pembentukan Badan Arbitrase PSSI dan juga berdasarkan pasal 69 Statuta PSSI. Yurisdiksi Badan arbitrase PSSI diatur dalam pasal 1 Regulasi Badan Arbitrase PSSI tentang Peraturan dan Acara Arbitrase yang menyebutkan bahwa arbitrase PSSI mempunyai wewenang untuk menangani sengketa antar anggota PSSI, atlet, pelatih. agen atlet dan/atau agen pertandingan ataupun pihak ketiga yang berkepentingan yang tidak diatur dalam kode disiplin PSSI, Kode Etik PSSI dan Badan Yudisial ad-hoc PSSI maka para pihak wajib membawa sengketa yang timbul di antara mereka ke arbitrase di hadapan Badan Arbitrase PSSI. Dari pasal tersebut dapat disimpulkan bahwa segala sengketa antar anggota PSSI, atlet, pelatih, Agen atlet dan/atau agen pertandingan ataupun pihak ketiga yang berkepentingan yang tidak diatur dalam kode disiplin PSSI, Kode Etik PSSI dan Badan Yudisial ad-hoc PSSI harus dibawa terlebih dahulu ke arbitrase PSSI.

Kedua, Komisi Status Atlet PSSI. Kewenangan Komisi Status Atlet PSSI ini ada berdasarkan pasal 23 Regulasi Status dan Transfer Atlet. Komisi Status Atlet mengadili kasus yang diuraikan dalam pasal 22 dan juga sengketa lain yang timbul karena penerapan peraturan ini berdasarkan pasal 24 dan Transfer Atlet PSSI dan pasal 1 
Regulasi Badan Arbitrase PSSI tentang Peraturan dan Acara Arbitrase terlihat tumpang tindih kewenangan karena baik Badan Arbitrase PSSI maupun Komisi Status Atlet sama-sama berwenang untuk menyelesaikan sengketa yang timbul diantara anggota PSSI dan atlet. Ini menimbulkan kebingungan kemanakah sengketa akan dibawa terlebih dahulu, ke Arbitrase PSSI terlebih dahulu ataukah ke Komisi Status Atlet terlebih dahulu.

Menurut penulis, hal tersebut tidak akan membingungkan jika saja terdapat pembagian lembaga penyelesaian sengketa seperti halnya pada DRC dan Players Status Committee FIFA yang telah dibagi secara jelas masing-masing kewenangannya dalam RSTP FIFA.

Hukum acara yang mengatur proses di Komisi Status atlet diatur dalam Regulasi Mengenai Hukum Acara Ajudikasi Sengketa Atlet di Komite Status Atlet. Pasal 3 ayat 1 Regulasi Badan Arbitrase PSSI tentang Peraturan dan Acara Arbitrase menyatakan pengajuan permohonan diajukan secara tertulis dengan menguraikan secara lengkap, jelas dan cermat, disertai dengan bukti permulaan yang cukup. Surat permohonan diajukan dengan mengirimkan ke alamat Sektretariat PSSI secara resmi dan diajukan kepada PSSI.

Dari uraian tersebut diatas, pada umumnya kontak kerja atlet sepak bola dengan klub adalah kontrak baku yang ditetapkan oleh asosiasi dimana mereka menetapkan untuk tidak memilih Pengadilan Negeri maupun Pengadilan Hubungan Industrial sebagai lembaga penyelesaian sengketa, namun memilih forum penyelesaian sengketa yang disedakan oleh FIFA maupun PSSI. Hal tersebut tidak melanggar ketentuan perundang-undangan, karena berdasarkan pasal 1338 BW mengenai kebebesan berkontrak dan ketentuan dalam UU Sistem Keolahragaan Nasional mengenai forum penyelesaian sengketa juga bersifat mengatur (regelentrecht) dan optional. Selain itu, dari beberapa lembaga penyelesaian sengketa yang tersedia, atlet sepakbola dapat menyelesaikan sengketa melalui arbitrase yang disediakan oleh FIFA dan PSSI berdasarkan kewenangan dan yurisdiksi masing-masing forum penyelesaian sengketa. Penyelesaian sengketa lewat arbitrase yang disediakan FIFA maupun PSSI dapat selesai lebih cepat, lebih paham sekaligus mempunyai pengetahuan lebih untuk menyelesaikan sengketa dibidang keolahragaan. Cepat inilah yang dibutuhkan atlet karena atlet dikejar dengan masa berakhirnya jeda kompetisi yang hanya sekitar 2-3 bulan saja.

Jika kita mengkaji kontrak kerja antara atlet (M) dengan klub (J) yang terjadi pada tanggal 1 Maret 2013. Pada pasal 21 mengenai arbitrasi, disebutkan bahwa jika terjadi perselisihan maka para pihak menyelesaiakan sengketa secara musyawarah mufakat dalam jangka waktu 30 (tiga puluh) hari. Jika gagal, maka para pihak memilih BAKI sebagai lembaga penyelesaian sengketa.

Pemilihan BAKI dalam penyelesaian sengketa kontrak atlet tersebut cukup beralasan karena pada saat itu belum terdapat lembaga arbitrase lain yang berkompeten menyelesaikan sengketa atlet lokal ditingkat nasional. Sehingga, pemilihan forum penyelesaian sengketa atlet kembali lagi pada isi klausul penyelesaian sengketa dalam masing-masing kontrak antara atlet sepakbola dengan manajemen klub. 


\section{KESIMPULAN}

Terkait dengan klausul dalam perjanjian kerja/kontrak kerja atlet sepakbola dengan pihak manajemen klub yaitu tunduk atau tidaknya atlet sepakbola kepada atauran UU Ketenagakerjaan, maka dalam hal ini atlet sepakbola tetap tunduk pada aturan UU Ketenagakerjaan dengang asas preferensi. Perjanjian kerja/kontrak kerja atlet sepakbola dan pihak manajemen klub yang ada telah memenuhi syarat sahnya perjanjian dalam $1320 \mathrm{BW}$ maupun dalam pasal 52 UU Ketenagakerjaan. Perjanjian berbentuk tertulis dan dibuat dalam bentuk perjanjian standar atau dapat disebut juga perjanjian baku. Perjanjian secara sepihak oleh pihak manajemen klub dan digunakan untuk semua atlet sepakbola yang dikontrak maupun yang akan dikontrak oleh pihak manajemen klub.

Upaya penyelesaian sengketa dalam sepakbola berbeda dengan sengkata di bidang perdata lainnya. Di dalam sengketa sepakbola hanya menggunakan penyelesaian non-litigasi yaitu penyelesaian sengketa diluar pengadilan, hal tersebut sesuai dengan pasal 21 perjanjian kerja atlet sepakbola profesional dan sesuai dengan pada pasal 88 UU No 3 Tahun 2005 tentang Sistem Keolahragaan Nasional. Diawali dengan musyawarah dan mufakat, jika musyawarah dan mufakat gagal dapat dilanjutkan melalui arbitrase atau alternatif penyelesaian sengketa sesuai dengan UU No. 30 tahun 1999, yang sudah ditentukan dalam perjanjian yaitu Badan Arbitrase Keolahragaan Nasional (BAKI) yang keputusan bersifat final dan mengikat para pihak yang bersengketa. Tetapi pada kenyataannya bahwa pihak manajemen klub tidak menggunakan cara penyelesaian yang tertera dalam kontrak, manajemen klub memberikan opsi atau pilihan untuk penyelesaian sengketa.

\section{SARAN}

Bagi atlet sepakbola profesional harus lebih teliti mebaca setiap perjanjian kerja/kontra kerja yang akan ditandatangani. Jangan sampai ketidakpahaman dan kekurang telitian atlet sepakbola menimbulkan sengketa dan kerugian. Atlet sepak bola harus didampingi oleh seorang manager dan perjanjian kerja yang dibuat harus melalui notaris.

UU Sistem Keolahragaan Nasional dan UU Ketenagakerjaan harus di perbaruhi, karena UU Sistem Keolahragaan Nasional dan UU Ketenagakerjaan saat ini kurang mengakomodir kepentingan atlet sebagai tenaga kerja dan terutama mengenai forum penyelesaian sengketa. Undang-Undang harus jelas dalam menentukan batasan pengertian sengketa keolahragaan kemudian forum yang dapat dipilih sebagai forum penyelesaian sengketa dan hukum yang diterapkan jika terjadi sengketa. Karena jika tidak, akan terjadi benturan sistem hukum, konflik norma, dan terjadi ketidakharmonisasian antara sistem hukum nasional dengan sistem hukum FIFA (Lex Sportiva).

\section{DAFTAR PUSTAKA}

Burgelijk Wetboek;

Undang-Undang Nomor 13 Tahun 2003 tentang Ketenagakerjaan

Undang-Undang Nomor 3 Tahun 2005 tentang Sistem Keolahragaan Nasional

Undang-Undang Nomor 30 tahun 1999 tentang Arbitrase dan Alternatif Penyelesaian Sengketa 
Peraturan Pemerintah Republik Indonesia Nomor 16 tahun 2007 Tentang Penyelenggraan Keolahragaan

Statuta FIFA

Statuta PPSI

A. Ichsan, 2000, Hukum Perdata IB, Pembimbing Masa, Jakarta

Adrian Sutedi, 2009, "Hukum Perburuhan", Sinar Grafika, Jakarta

Agusmidah. 2011,Dilematika Hukum Ketenagakerjaan Tinjauan Politik Hukum, Sofmedia,Jakarta

Agus Yudha Hernoko, 2010, Hukum Perjanjian Asas Proporsionalitas dalam Kontrak Komersial, Kencana Prenada Media Group, Jakarta

Ahmad Rizki Sridadi, 2016, Pedoman Perjanjian Kerja Bersama, Empat Dua Media, Malang

Asri Wijayanti, 2010, Hukum Ketenagakerjaan Pasca Reformasi, Sinar Grafika, Jakarta

C.S.T Kansil, 2009, Kamus Istilah Aneka Hukum, Jala Permata,Jakarta

Devi Rahayu, 2011, "Hukum Ketenagakerjaan Teori dan Studi Kasus", Elmatera,Yogyakarta

F.X. Djumiadji, 2010, Perjanjian Kerja, Edisi Revisi, Sinar Grafika, Jakarta

Hinca Panjaitan, 2011, "Kedaulatan Negara Vs Kedaulatan FIFA”,Kompas Gramedia ,Jakarta

Imam Soepomo, 2003, Pengantar Hukum Peburuhan, Djambatan, Jakarta

Jhonny Ibrahim, 2008, Teory dan Metodelogi Penelitian Hukum Normatif, Bayumedia, Malang

Lalu Husni, 2006, Pengantar hukum Ketenagakerjaan Indonesia, Grafindo, Jakarta.

Mariam Darus Badrulzaman, 2005, "Aneka Hukum Bisnis”, Alumni, Bandung

Munir Fuady, 2000, “Arbitrase Nasional”, cetakan I, Citra Adity Bakti, Bandung.

Peter Mahmud Marzuki, 2010, Penelitian Hukum, Kencana Pranada Media, Jakarta

Philipus M. Hadjon, 1987. Perlindungan Hukum Bagi Rakyat Indonesia, Bina Ilmu, Surabaya

Salim H.S,2003, "Perkembangan Hukum Kontrak Innominaat di Indonesia", Media Grafika.

Setiawan, 1977, Pokok-Pokok Hukum Perikatan, Bina Cipta,Bandung

Subekti dan Tjiptosudibio, Burgelijk Wetboek, Terjemahan Paramita, Jakarta.

Sutjipto Rahardjo, 2000, Ilmu Hukum, Citra Aditya Bakti, Bandung.

Hinca Panjaitan, "Memperkenalkan Lex Sportiva di Indonesia Problema dan Tantangan Dunia Olahraga di Indonesia dan Keterkaitannya denganAspekHukum",http:/ /www.lexsportiva.co.id/?lang=\&page=content\&ids $=6$ \&id $=29$

Forum Penyelesaian Perselisihan dalam Kontrak Pesepakbola diIndonesia Masih Berbedabeda, http://www.appi-online.com/forum-penyelesaian-perselisihan-dalamkontrak-pesepakbola-diindonesia-masih-berbeda-beda 
Jurnal Media Hukum dan Peradilan

Program Pascasarjana Universitas Sunan Giri Surabaya ISSN : 2654-8178 (Online) - 2442-7829 (Print)

Ken Foster, "Is There a Global Sport Law", http://www2.warwick.ac.uk/fac/soc/law/elj/eslj/issues/volume2/number1/foster. pdf

Ridwan Khairandy, 2013, “ Hukum Kontrak dalam Prespektif Perbandingan”, e-book

. Ahmad Quroni," Meneropong Keolahragaan Nasional”, Pdf 


\title{
LETTER OF ACCEPTANCE
}

\author{
Dear, Syifa Usdurah
}

\begin{abstract}
We would like to inform you that your paper titled "PERLINDUNGAN HUKUM BAGI ATLET SEPAKBOLA PROFESIONAL INDONESIA TERHADAP MANAJEMEN KLUB YANG MELAKUKAN WANPRESTASI" has been accepted for publication in Jurnal Media Hukum dan Peradilan, Program Pascasarjana Universitas Sunan Giri Surabaya ISSN : 2654-8178 (Online) - 2442-7829 (Print) Volume 5, Number 2 2019. Based on the Recommendation of the Editorial Board without any major corrections in the content submitted by the researcher. Please visit the link below to download the paper:
\end{abstract}

\section{https://ejournal-pps.unsuri.id/index.php/imhp/article/view/92}

This letter is the official confirmation of acceptance of your research paper.

Your research work is licensed under a Creative Commons Attribution 4.0 International License.

Kindly acknowledge the Paper acceptance

Thank \& Regards.

Chief Editor of

Jurnal Media Hukum dan Peradilan

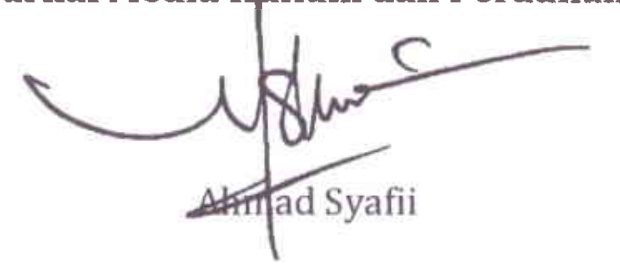

